\title{
Understanding unmet need for family planning
}

\author{
Srishti Singh $^{1 *}$, Meenakshi Kalhan ${ }^{1}$, J. S. Malik ${ }^{1}$, Anuj Jangra ${ }^{1}$, Nitika Sharma ${ }^{1}$, Srijan Singh ${ }^{2}$
}

${ }^{1}$ Department of Community Medicine, Pt. B. D. Sharma PGIMS, Rohtak, Haryana, India

${ }^{2}$ Department of Pediatrics, Maulana Azad Medical College, New Delhi, India

Received: 13 March 2018

Accepted: 21 April 2018

\section{*Correspondence:}

Dr. Srishti Singh,

E-mail: srishti16june@gmail.com

Copyright: (c) the author(s), publisher and licensee Medip Academy. This is an open-access article distributed under the terms of the Creative Commons Attribution Non-Commercial License, which permits unrestricted non-commercial use, distribution, and reproduction in any medium, provided the original work is properly cited.

\begin{abstract}
Unmet need represents the gap between women's reproductive intentions and their contraceptive behavior. There are some 225 million women in the world who want to use safe and effective family planning methods are unable to do so. Control over fertility is very important not only because of its far-reaching implications on prosperity and overall growth of the nation, but also because of its impact on the freedom of young women to lead life of their own choice. Reduction in unmet need for family planning is critical for the overall development of the society. Combination of the mutually reinforcing effects of investments in education, health and family planning programmes is needed.
\end{abstract}

Keywords: Contraceptives, Family planning, Need, Unmet

\section{INTRODUCTION}

Every day about 830 women die from preventable causes related to pregnancy and childbirth and $99 \%$ of these maternal deaths occur in developing countries. ${ }^{1}$ Unintended pregnancies are an important cause of illness during pregnancy, complications at the time of birth and maternal deaths apart from contributing to higher fertility rates and population growth. The continuous increase in population is a serious global concern and a major obstacle for the socio-economic development. According to World Population Prospects 2015 Revision, India (1.3 billion) remains the second most populous country in the world only next to China. ${ }^{2}$ India harbours $18 \%$ of the world's population in only $2.4 \%$ of the global land mass. Coincidentally it also houses almost $17.3 \%$ of the world's protected couples and $20 \%$ of the world's eligible couples with unmet need. ${ }^{3}$ Therefore, large population size of India not only impacts its own but also the global health indicators. Control over fertility is important not only because of its far-reaching implications on prosperity and overall growth of the nation, but also because of its impact on the freedom of young women to lead life of their own choice.

India launched the National Family Planning Programme in 1952 thus becoming the first country in the world to do so. Since then, the family planning programme in India has under gone dramatic transitions; evolved from a targeted approach to a target free approach and has now been anointed as a critical intervention to reduce maternal and child mortality and morbidity beyond a simple strategy for achieving population stabilisation. Despite these measures, India's population continues to grow at a decadal growth rate of $17.64 \%$ with a crude birth rate of 21.6 per 1000 estimated mid-year population. ${ }^{4}$ The desired Total Fertility Rate (TFR) of 2.1 could not be achieved till date. ${ }^{5}$

\section{Concept of unmet need for family planning}

Unmet need for family planning is a valuable concept that is widely used for advocacy, development of family planning policies and the implementation and monitoring 
of family planning programmes worldwide. Unmet need represents the gap between women's reproductive intentions and their contraceptive behavior. ${ }^{6}$

Women with unmet need are those who are fecund and sexually active but are not using any method of contraception, and report not wanting any more children or wanting to delay the next child. ${ }^{7}$ Once derived, the figure of unmet need for family planning can be broken down into unmet need for spacing (women who want a child after two or more years) and unmet need for limiting (women who want no more children).

It has been estimated that there are some 225 million women in the world who want to use safe and effective family planning methods are unable to do so because they lack access to information, services, or the support of their partners or communities. Most of these women live in 69 of the poorest countries on earth. ${ }^{8}$ Unmet need is high among certain groups such as adolescents, migrants, urban slums, refugees and women in postpartum period.

Unmet need for family planning has received an unprecedented level of scrutiny since it is included in Millennium Development Goals. According to MDG 2015 Report, 12\% of married or in-union women of reproductive age worldwide wanted to delay or avoid pregnancy but were not using any method of contraception. ${ }^{9}$ When users of traditional methods are counted as having an unmet need for family planning, $18 \%$ of married or in-union women worldwide were estimated to have an unmet need for modern methods in 2015. ${ }^{10}$ Reproductive health issues including universal access to family planning have also been targeted in the Sustainable Development Goals. ${ }^{11}$ According to National Family Health Survey-3, the unmet need in India was $12.8 \%$ including $6.2 \%$ for spacing and $6.6 \%$ for limiting. ${ }^{12}$ India framed its Vision FP2020 as a part of its efforts to achieving the London Summit Goals of family planning. Vision FP2020 for India is not just about providing contraceptive services to additional 48 million users but aversion of 23.9 million births, one million infant deaths and over 42000 maternal deaths by the year $2020 .^{3}$

There are various reasons responsible for unmet need of family planning like limited choice and access of family planning methods particularly among young, poor or unmarried people, fear of side-effects, cultural or religious opposition, poor quality of available family planning services and gender based barriers. ${ }^{8}$ Family planning strategies especially emergency contraception should reach the poor, rural women, who do not have access to much of the resources or the private sector. It is time to focus serious attention on strengthening the health system's capacity to reach the unreached and to improve service quality.

Family planning programmes in developing countries like India have been experiencing a phenomenon called as "the leaking bucket" which highlights the fact that meeting women's desire to reduce unwanted fertility will become easier once these programmes pay more attention to contraceptive discontinuation. ${ }^{13}$ To plug the hole in the leaking bucket there is the need of expanding women's choice of methods, helping them to select the method most appropriate to their current reproductive needs and encouraging women to switch methods as their reproductive needs or method preferences may change over time.

Women's advancement may impact and provide solutions to five specific global challenges including demography, leadership, food security and agriculture, sustainability and resource scarcity and conflict. ${ }^{14}$ In sum, progress made in improving social development in addition to the progress made in strengthening the ongoing family planning programme will contribute to the future pace of fertility and decline in unmet need. ${ }^{15}$

\section{CONCLUSION}

Reduction in unmet need for family planning is critical for the overall development of the society. Combination of the mutually reinforcing effects of investments in education, health and family planning programmes is needed. Access, availability and affordability to wide range of safe and effective contraceptive methods particularly in the public sector apart from counseling and motivation would reduce the unmet need for family planning and provide a healthier life to women and children.

\section{Funding: No funding sources \\ Conflict of interest: None declared \\ Ethical approval: Not required}

\section{REFERENCES}

1. World Health Organization. Maternal Mortality. WHO Factsheet N0348. Geneva: World Health Organization; 2015. Available from: http://www. who.int/mediacentre/factsheets/fs348/en/. Accessed on 02 September 2016.

2. United Nations, Department of Economic and Social Affairs, Population Division. World Population Prospects: The 2015 Revision, Key Findings and Advance Tables. Working Paper No. ESA/P/WP.241. New York: 2015. Available from: www.un.org/en/development/desa/publications/worl d-population-2015revision.html, Accessed on 02 September 2016.

3. Ministry of Health and Family Welfare, Family Planning Division. India's 'Vision FP2020'. New Delhi: Government of India; 2014. Available from: www.familyplanning2020.org>india. Accessed on 02 September 2016.

4. Office of the Registrar General and Census Commissioner. Provisional Population Totals: India Census 2011. New Delhi: Ministry of Home Affairs, 
Government of India; 2011. Available from: www.censusindia.gov.in/vital_statistics/vital_rates/vi tal_rates.aspx. Accessed on 02 September 2016.

5. Office of the Registrar General. Sample Registration System Bulletin. New Delhi: Ministry of Home Affairs, Government of India; 2013 Sep. Available from: http://censusindia.gov.in/vital_statistics/SRS_ Bulletins/SRS_Bulletins-September_2013.pdf. Accessed on 03 September 2016.

6. Bongaarts $\mathrm{J}$, Bruce $\mathrm{J}$. The causes of unmet need for contraception and the social content of services. Studies in Family Planning. 1995;26(2):57-75.

7. World Health Organization. Sexual and Reproductive Health. Unmet need for family planning. Geneva: World Health Organization; 2013. Available from: http://www.who.int/reproductive health/topics/family_planning/unmet_need_fp/en/ Accessed on 10 September 2016.

8. World Health Organization. Family Planning. WHO Factsheets N0351. Geneva: World Health Organization; 2015 May. Available from: http://www.who.int/mediacentre/factsheets/fs351/en/ Accessed on 05 September 2016.

9. United Nations. The Millennium Development Goals Report 2015. New York: United Nations; 2015. Available from: https://www.un.org>MDG2015 rev(July1). Accessed on 10 September 2016.

10. United Nations, Department of Economic and Social Affairs, Population Division. Trends in Contraceptive Use Worldwide 2015. New York: United Nations; 2015. Available from: www.un.org $>$ publication $>$ pdf $>$ family. Accessed on 15 September 2016.

11. United Nations. Transforming our world: The 2030 agenda for sustainable development. New York:
United Nations; 2015. Available from: https://sustainabledevelopment.un.org?post2015/tran sformingourworld Accessed on 15 September 2016.

12. International Institute for Population Science (IIPS) and Macro International. National Family Health Survey (NFHS-3), 2005-2006, India: Key Findings. IIPS, Mumbai. Available from: https://dhsprogram.com>FRIND3-Vol2 Accessed on 17 September 2016.

13. Jain A. The Leaking Bucket Phenomenon in Family Planning. New Delhi: Population Council; 2014 Sep. Available from: https://champions4choice.org/2014/ 09/the-leaking-bucket-phenomenon-in-familyplanning/ Accessed on 20 September 2016.

14. Global Agenda Council on Women's Empowerment 2011 - 2012. Five Challenges, One Solution: Women. Geneva, Switzerland: World Economic Forum; 2013 March. Available from: https://www. weforum.org/reports/five-challenges-one-solutionwomen/ Accessed on 20 September 2016.

15. International Council on Management of Population Programmes, United Nations Population Fund. Family planning in Asia and the Pacific: Addressing the challenges. Selangor, Malaysia: International Council on Management of Population Programmes; 2012. Available from: https://www.icomp.org.my> new $>$ fpconsultation. Accessed on 20 September 2016.

Cite this article as: Singh S, Kalhan M, Malik JS, Jangra A, Sharma N, Singh S. Understanding unmet need for family planning. Int J Reprod Contracept Obstet Gynecol 2018;7:2524-6. 